\title{
THE CHALLENGES OF PREACHING TO POOR WOMEN COMMUNITY (STUDIES OF PREACHING COMMUNICATION TO POOR WOMEN COMMUNITY IN THE TALLO DISTRICT MAKASSAR)
}

\author{
Nur Setiawati \\ Islamic Religion Faculty of Indonesia Moslem University \\ Jl. Urip Sumihardjo Km 5. Makassar, Indonesia \\ Email:aghiebajiminasa@gmail.com \\ Bisyri Abdul Karim \\ Islamic Religion Faculty of Indonesia Moslem University \\ Jl. Urip Sumihardjo Km 5. Makassar, Indonesia \\ Email:bisyrikarim@yahoo.com
}

Article received February $2^{\text {th }}, 2021$; Article revised April 1 ${ }^{\text {st }}, 2021$; Article approved May $8^{\text {th }}, 2021$

\begin{abstract}
This study aims to analyze the access and needs of poor women in the Tallo district in relation to preaching activities. This study used a preaching communication perspective to identify the challenges of preaching strategies and empowering poor women in urban areas. This study used a mixed method between quantitative and qualitative research. The data was collected through literature study, observation, questionnaires, and in-depth interviews. Data analysis used in this study was the interactive model of Miles \& Huberman. The results showed that most of the poor women in the Tallo district defined preaching as a lecture and face-to-face activity. They consider that the government should be more responsible for its implementation rather than other organizations or communities. Most of them prefer the theme of worship, family, and morals when dealing with preaching messages. The preferred media for delivering preaching is through lectures and face-toface compared with electronic and social media.
\end{abstract}

Keywords: challenges, preaching, poor women, urban areas

\section{INTRODUCTION}

$\mathrm{P}$ overty is a condition of limited ability to properly meet life necessities, such as limitations in income, skills, health conditions, control of economic assets, or access to information (Isdijoso et al., 2016). Poverty is also a complex problem influenced by various interrelated factors, including income level, health, education, access to goods and services, location, etc. Poverty is no longer understood only as an economic inability but also a failure to fulfill the basic rights of different treatment for a person or group of people in living a life with dignity.

This phenomenon of poverty has become a "lifestyle" for urban communities in particular because they always specialize in themselves as a group that always expects help from other parties. There are various ways that the government has done to reduce the amount of poverty in our country. However, the poverty rate remains high due to various factors, including several parties who abuse the use of aid distributed by the government and the number of people who are capable in terms of financially but consider themselves still lacking in fulfilling all their needs so that they consider themselves to be poor (Muslimin, 2013).

Dealing with the poverty conditions experienced by women, based on research results, it can be generalized that poverty is mostly suffered by women (Todaro, 2000). According to Todaro, in the third world, the facts reveal that women and their children suffer the most from malnutrition, the least receive health services, clean water, sanitation, and various other forms of social services.

Todaro argues that many women are household heads, have low capacity to generate their own income, and have limited control over their husband's income. It was explained that women have limited access to education, decent work in the formal sector, 
social benefits, and job creation programs created by the government. Thus, the increasing underdevelopment of women is not because they are unworthy and unable to participate in the development, but because of unfair treatment. The work they do is not considered profit-generating work.

From this situation, the term feminization of poverty is widely used. The feminization of poverty is "the collective growth of the population of women living below the poverty line" (Moghadam, 2005). Feminization of poverty is defined as a change in poverty that deviates from attacking women or female household heads. More specifically, it increases the difference in poverty levels between women and men or between households' spouses. It can also be defined as an increase in gender role inequality.

The poverty of women (feminization of poverty) can be seen from several aspects, namely: (1) women's access to jobs; (2) access to equal pay; (3) access to education; and (4) workload. There is limited access to the labor market, and women's tendency to enter the labor market is much smaller than men while entering the labor market. In Indonesia, there is about $85.3 \%$ male participation rate for all levels of education and $46.3 \%$ for female labor participation (Noerdin et al., 2006: 8). Finally, more women are in the informal sector.

In addition to the poverty conditions experienced by women, the challenge of preaching and women's empowerment needs to be a special concern. The religious awareness of some people can be properly developed and directed. The individuals have different religious awareness levels. According to Soedarsono in Hasanah (2013), religious awareness of the majority of the poor is avoiding economic pressure, providing a sense of security, calm, peace, and prosperity. This fact does not apply to the urban poor women's community, who believe that religion is a formal institution that has no meaning and benefits for life. Religion is a formal requirement for the recognition of social identity in society. If there is a wrong understanding of religion, it will cause laziness and indifference to the implementation of religious teachings. This condition is a kind of poor people's unconsciousness in understanding and living up to their religious teachings.

Dealing with the social and economic conditions and situations experienced by poor women in the Tallo district, Makassar, it is important to know how to implement the right preaching strategy according to the situation and conditions of the community. It then becomes a challenge in building models and strategies of preaching communication in poor women communities in urban areas. The research questions are: first, how do they understand preaching, and who are the figures considered needed and responsible for the implementation of preaching in the Tallo district, second, what are desirable preaching messages, and third, what is accessible preaching media.

In accordance with the research problems described earlier, this study aims to (1) identify the understanding of preaching and the parties that are needed and are considered responsible for the implementation of preaching for poor women in the Tallo district, (2) identify the preaching messages that are of interest, (3) identifying preaching media that are easily accessible to poor women in the Tallo district.

\section{LITERATURE REVIEW}

According to Wahyu Ilaihi, communication can be defined as the process of conveying by communicators to communicants through the media, which has certain consequences. In its implementation, communication can be done either primary (direct) or secondary (indirectly).

Communication will be successful if the message conveyed by the communicator matches the frame of reference, which guides to the experience and understanding the communicant has received. Communication activities are, in principle, the activity of exchanging ideas in a simple way. Thus, communication activities can be understood as delivering messages or ideas, the meaning of one party to another, with the aim is to produce mutual agreement on the idea or message conveyed (Wahyu Ilaihi, 2010).

The word da'wah (preaching), etymologically or linguistically, comes from Arabic, namely d $a^{\prime} a \sim$ yad'u $\sim$ da'watan which means to invite, call, call. The names for 
people who preach a lot are da'i-daiyah, ustadz-ustadzah, buya, sheykh. People who are preached are called mad'u (Munir, 2013). According to Muhammad Natsir, preaching implies an obligation for a Muslim in amar ma'rruf nahi mungkar. Meanwhile, Shaykh Muhammad Abduh said that preaching is calling for goodness and preventing evil from being wrong, which is obligatory for every Muslim (Saputra, 2010).

In the context of preaching, an understanding of the needs of the preaching target is necessary. Preaching among the poor will not be effective by just lecturing, but it will be more effective if preaching is carried out by supporting them, providing food, clothing, and so on (Munir et al., 2003). According to Munir, ideally, effective preaching should refer to the community to improve the quality of Islam and the quality of life. Preaching not only requires things that are religiously Islamic but also fosters a work ethic. The success of preaching is determined by the attitude and real interactive activities that bring people closer to their needs, directly or indirectly affecting the increase in the quality of religiousness.

According to Zaini (2017), preaching does not have to be conveyed through the pulpit. Preaching also pays attention to the needs of its target (mad'u). Besides increasing the quality of faith, preaching is also expected to improve the quality of life of mad'u because the target of preaching has various problems. From a geographical point of view, the targets of preaching are those who live in urban and rural areas. Mahfudh in Zaini (2017) says that preaching activities are basically giving motivation to others, so it is necessary to pay attention to the target group's needs. Moreover, the purpose of preaching is the achievement of welfare in the world and the hereafter. In fact, preaching in this sense is to empower the community.

Women experience wage discrimination problems. Female workers in Indonesia receive lower wages than male workers. According to data presented by Edy Prijono in Kamurur (2009), on average, female workers only receive $74 \%$ of the wages received by male workers. Wage discrimination is the differentiation of workers' wages on work, qualifications, working hours, performance, and other conditions, which are all the same. Therefore, wage distinctions are made solely because of gender considerations, said Edy Prijono. Ministerial Regulation No. 04/1988 also strengthens such discrimination by allowing female workers not to get health benefits if their husbands have received benefits from the same company or other companies.

Due to the gender division of labor, women are obliged to perform domestic or household tasks, such as washing dishes, washing clothes, looking after children, and cleaning the house. Meanwhile, men are obliged to earn a living for the family (public duties). This task will be difficult for lowincome families who have to survive in the city. Poor women not only do their compulsory duties in the domestic sphere, but they also have to work in the public sphere to increase their families' income.

\section{Conceptual Framework}

This study used a preaching communication theory in identifying the challenges of preaching to poor women in urban areas. Thus, the use of combined methods (mixed methods) between quantitative and qualitative is very important and relevant to see the coverage of the amount of data and its quality. By using the explanatory sequential model, the quantitative data were analyzed separately. Quantitative data were used to deepen the qualitative data analysis further. Similarly, data interpretation followed quantitative and qualitative results. Qualitative findings helped to explain quantitative results. Qualitative data helped to provide deeper and more insightful ideas for quantitative results.

\section{RESEARCH METHOD}

This research used a combination method of quantitative and qualitative (mixed method). The use of quantitative and qualitative approaches simultaneously (in combination) was intended to understand research problems deeply. The design of this study consisted of two phases, the collection and analysis of quantitative data following the collection and analysis of qualitative data. The explanatory method was used to describe, elaborate, or explain quantitative findings (Masrizal, 2011). 
Subjects in this study were poor women in the Tallo district, Makassar, with a sample focus and respondents of poor women in Lembo, Kalukubodoa, and Rappokalling. The group of poor women who were the samples and respondents in this study came from the following backgrounds: housewives, food stall owners, laborers, scavengers, beggars, and hawkers, with a total of 102 people. The research was conducted in 2020 for four months.

Since this research used a mixed method, data collection was carried out by library research, field observations, questionnaires, in-depth interviews, and documentation. Furthermore, quantitative and qualitative data were analyzed separately. Quantitative data were used to follow up and interpret qualitative data. Data were analyzed using an interactive model by Milles and Huberman (1992), including data reduction, data display, data verification, and conclusion.

\section{DISCUSSION}

\section{Population Description and Poverty Situation in the Tallo District}

The Tallo District is one of 14 Districts in Makassar that borders the north of the Makassar Strait, the east of Tamalanrea District, the south of Bontoala District and Panakukang District, and the west of Bontoala District and Ujung Tanah District. The Tallo District consists of 15 urban villages with an area of $5.83 \mathrm{~km}^{2}$. In 2015-2016, the population of the Tallo District had increased. In 2018, there were 140,023 inhabitants. Based on gender, the total population of men was around 70,183 people and women were around 69,840 people (BPS Kota Makassar, 2019). Based on the Makassar Social Service data, the number of poor people in the Tallo district in 2019 is 48,246 people with 11,387 families (Dinas Sosial, 2019).

One of the characteristics inherent in the existence and condition of the poor is that they live in a slum area. Slum areas are identical to poor people. The impact of urbanization is evident in Makassar, South Sulawesi. In the fifth largest city in Indonesia, population movement that eventually settles in urban areas triggers slum conditions. An example of slum areas in the Tallo district is in the Tallo sub-districts.
Slum typology in this area consists of settlements on the water's edge, above the water, and in lowlands. Characteristically, the Tallo sub-districts are located in a coastal area, riverbanks, and a port development functional area. The physical condition of the slum area in the Tallo can be seen from the indicators of residential buildings, environmental roads, and environmental drainage. The factors affecting poverty can be seen in each characteristic, namely: first, low-income levels are caused by dependence on the money economy, second, poor health conditions are caused by slum, dense and unhygienic living conditions, and an unhealthy living environment due to pollution, and third, low levels of education are caused by obstructed access to education due to limited school capacity, inability pay for school fees, books, and uniforms.

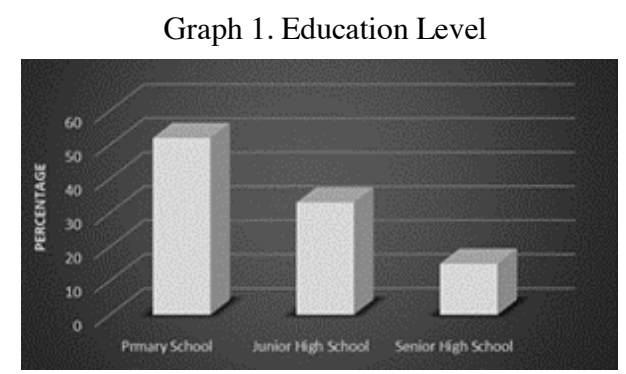

Regarding the level of education, the results of the data analysis showed that the average level of education of poor women in the Tallo district is Primary School graduates, $52 \%$. Then, $33 \%$ have graduated from Junior High School. Those who have graduated from Senior High School are only 15\%. More details can be seen in graph 1 .

In this regard, generally, Indonesia is quite good at providing access to basic education. The participation rate of basic education reaches more than $97 \%$ for both men and women. But unfortunately, access to education is decreasing at the level of further education. The reduced rate of continuing school to a higher level is also accompanied by a higher rate of difference based on gender.

Therefore, the linkage between the level of education and access to work is very clear, especially in the labor market for poor women in the Tallo district. The results of the research data analysis showed that most of the poor women in the Tallo district sell fried foods (36\%), followed by those who sell cakes $(12 \%)$, as scavengers (10\%), and domestic 
workers (9\%). Some (5\%) are heads of households, and the rest (28\%) are ordinary housewives. Details of the percentage description of the type of work can be seen in graph 2.

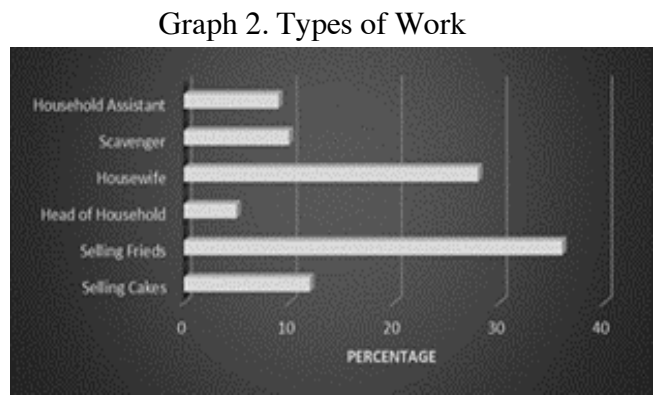

Some of the urban poor women still live in slum areas. Some landlords could raise sufficient funds to upgrade their housing to middle-class standards, while others remained in the simplest of shacks, unable to make any improvements. One of the serious problems faced by urban poor women is the lack of security of ownership. Without legal permission to occupy the land, they can be evicted by the landowner at any time. Apart from making life more unclear daily, the daily threat of eviction keeps residents of these informal settlements from wanting to invest in upgrading their housing or settlement.

Regarding the level of house ownership or residence for poor women in the Tallo district, the results of data analysis showed that only a small proportion (36\%) claim to live in their own house. The rest mostly still live or occupy rented houses (64\%). The description of the percentage of ownership can be seen in Graph 3. Graph 3. Accupied House

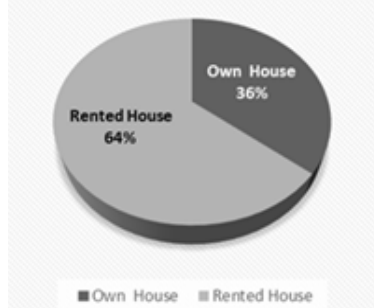

\section{Understanding About Preaching}

Conceptually, preaching can be divided into bil lisan and bil hal preaching. Bil lisan preaching emphasizes verbal activities in lectures, speeches and the delivery of religious messages. In contrast, bil hal preaching emphasizes concrete actions in work activities, social charities, and the implementation of work programs. In reality, bil lisan and bil hal preaching can be realized simultaneously.

The data analysis results showed that the poor women in the Tallo district still dominantly define the activity of preaching as a lecture or direct dialogue with a lecturer or $d a^{\prime} i$. They perceive that preaching is giving examples of good behavior. Few argue that preaching is assisting the poor or marginalized communities.

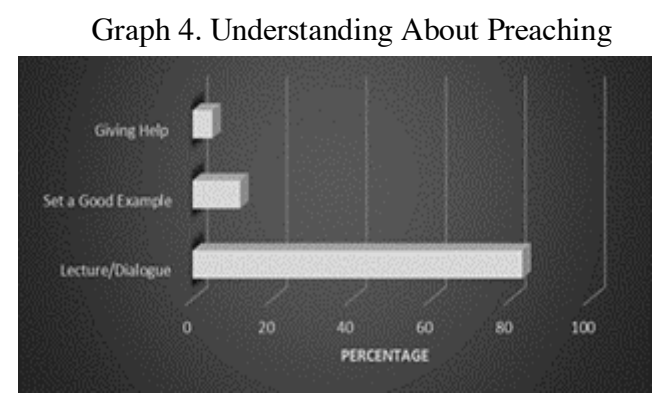

The details of the percentage can be seen in graph 4 , which shows that most of the poor women $(83 \%)$ know more about preaching activities through lectures or dialogues. The rest (12\%) believe that preaching must provide a good example so that their behavior can be a role model as an example of learning for others. While a small proportion (5\%) know and are accustomed to the presence of preaching by assisting both material and non-material.

Most of the poor women in the Tallo district, both in rural and urban areas, still define preaching as activities which are identical to tabligh (community groups meeting), religious lectures, recitation in Mosques, tabligh akbar (mass meeting), istighasah, and so on. This understanding is related to the preaching activities carried out by preachers with mad'u as the target of preaching either individually or in groups. It is also closely related to the understanding and experience of oral preaching and direct dialogue with the speaker. The public can ask questions and hear the answers to daily social and religious problems directly from the speaker.

Dealing with their understanding of preaching with a model of assisting, this is closely related to the behavior of sharing and giving alms. Almsgiving is a kind of preaching movement that is used to bring positive changes in society. Thus, it cares for others and creates a good relationship between people. 
For example, the organizations led by Yusuf Mansur, namely Darul Qur'an and Wisata Hati, are groups that are giving alms and facilitating the community to give alms. According to Yusuf Mansur, the relationship between alms and the preaching movement is to place alms as one of the strategies to convey amar ma'ruf nahi munkar (do good things and prevent evil). Giving charity will make people aware that humans' properties are not all their rights but the rights of others (Hasan Bastomi, 2016).

\section{Considered Responsible Parties Carrying Out Preaching Activities}

The communicator ethos largely determines the effectiveness of preaching communication. Ethos is a person's self-value, which combines cognition, effect, and conation. Cognition is the process of understanding which is concerned with thinking. Affection is generated by an external stimulus. Meanwhile, conation is psychology related to effort and struggle. Thus, the communicator's preaching (preaching message) to the communicant will be communicative if there is a similar process between preachers and mad'u involved in the process.

The results of the analysis showed that four main figures which are expressed and become the attention and desire of poor women in preaching activities in the Tallo district, Makassar, are government (34\%), community groups (29\%), local religious leader $(21 \%)$, and community organizations $(16 \%)$. From the four elements, the government gets the most coveted portion (first rank), followed by community groups (second rank), local religious leader (third rank), and finally, community organizations. The sequence of those components can be seen in graph 5 .

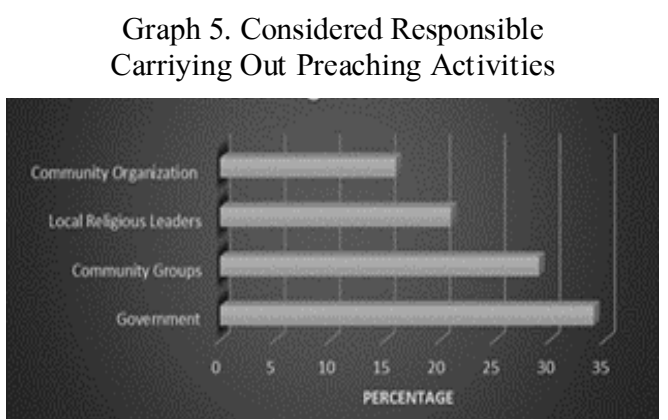

The first rank is related to the presence and responsibility of the state or government. In this case, the government has a role and responsibility to respect, fulfill, and protect its citizens to increase their welfare, both materially and spiritually. It includes preparing policies, planning and implementing preaching activities among the poor, especially poor women in urban areas. In Islam, the state must create programs and facilities that can overcome poverty, guarantee a decent life for Muslims, and build a spirit of solidarity in society.

The second rank is the role of community groups. Groups or communities in the local community significantly influence building awareness and community participation in preaching activities. These community groups include communities that are members of the recitation group, savings and loan groups, and majelis taklim. It will later be closely related to other figures needed in preaching, such as local religious leaders (Ustadz or Imam), who are always the source of reference and role models for these community groups.

The need for solidarity interactions and social roles and relationships among residents in a particular urban community is considered very important. As is well known, urban society is usually synonymous with heterogeneous, individualistic, materialistic, and modern which are in the area of tall buildings, many entertainment places, and dense settlements. Also, the urban population varies greatly from origin, ethnicity, language, and work. The social interaction of the urban community is in accordance with characteristics such as having an individualistic nature, so the relationship with each other is impersonal, an indirect relationship based only on common interests.

In the third rank is the local religious leader (Ustadz/Imam). In general, Imam is a cleric or scholar. In this case, Imam as a scholar has a role and function as a driving force (inspiratory, motivator, catalyst, and dynamic) towards social movements. Thus, the scholars will have a high bargaining position (Djaelani, 1990). Ulama can be interpreted as guardians, disseminators, and interpreters of Islamic teachings and Islamic law, and the preserver of the continuation of the Islamic community's 
history, religious spirituality, and intellectuality. The existence of religious figures such as Ustadz or Imam is considered quite important in addition to their capacity to understand the Al-Qur' an and Hadith. Also, it includes their ability to understand situations and conditions, anticipate community development, and lead and guide people in carrying out their obligations as the ummah (Muslim community).

The fourth rank is community organizations. The scope of community organizations here is very broad, not only community organizations with a large mass base such as Nahdlatul Ulama (NU), Muhammadiyah, Wahdah Islamiyah, Muslimat NU, Aisyiah, and Majelis Taklim but also communities that have concerns in the preaching and humanity.

Makassar is a city that implements religious values, which is proven by the dynamics of ta'lim activities held by Islamic community organizations, such as Nahdlatul Ulama, Muhammadiyah, and other community organizations. Developing the preaching of Islamic teachings cannot be separated from Islamic community organizations. Socioreligious of Islamic community organizations has an important role in advancing people's understanding of Islamic teachings. If all these mass organizations operate in harmony and have the same vision and mission, to help and defend the religion of Allah. In that case, people will not be swayed in confusion and will not be easily influenced by other religions. The role of socio-religious organizations is to disseminate Islamic teachings, including Islamic law, on the basis of a firm aqidah. Islamic organizations have a significant role in developing Islamic preaching.

\section{Preferred Preaching Messages}

The message referred to in preaching communication is what one delivered by the $d a^{\prime} i$ to the mad'u. In communication terms, messages are also called content or information. Based on the way of delivery, preaching messages can be conveyed face-toface or by using means. Preaching communication messages have a definite purpose. It will determine the technique, whether it is information techniques, persuasion techniques, or instructional techniques (Ilaihi, 2010).

Due to the data analysis, the findings showed four main themes of preaching messages that are a necessity for the poor women in the Tallo district. Details of the theme of the preaching message along with the rankings most needed and interested by the Tallo poor women are worship (36\%), family (26\%), death/afterlife (21\%), and morals (17\%). All of those illustrations of the sequence and percentage can be seen in graph 6.

Graph 6. Preferred Preaching Messages

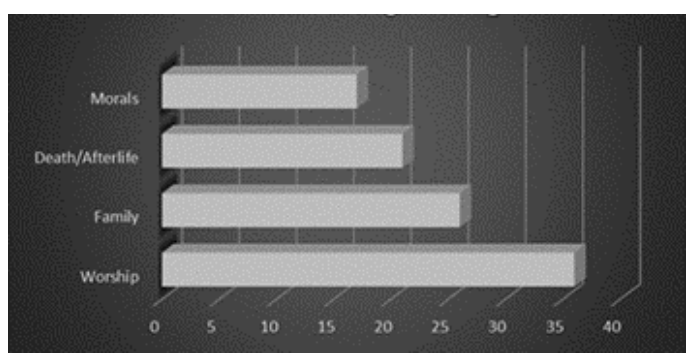

Despite facing appalling social and economic situations, the preaching message about worship is still quite attractive to poor women in the Tallo district. They realized that this is related to the obligation to worship as a form of worship of a servant to his Lord, which is done by humbling himself as low as possible, with a sincere heart in ways determined by religion. Thus worship is an absolute element in religion. However, the practice of worship in Islam must not neglect the obligations related to worldly needs. Humans need to work to make ends meet and interact and cooperate with others because humans cannot live without others' help.

Religious activities originate from the Al-Quran and Hadith so that they can be directed towards the path to the pleasure of Allah. The purpose of religious activities is to change knowledge, behavior, body and spirit, and required abilities to live in the world and the hereafter. It also includes objectives related to society, including community behavior, individual behavior in society, changes in community life, enriching community experience. Therefore, it can be concluded that the purpose of worship activities is to create good characteristics and behaviors in its role as a creature related to other creatures and its relationship with the Khaliq, Allah SWT. 
The next level relates to the theme of the sakinah family or family happiness. A happy family is considered critical for the emotional development of its members (especially children). This happiness is obtained when the family can play its function properly. The basic function of the family is to provide a sense of belonging, security, affection and develop good relationships among family members. Educational experts agree that love, tenderness, and sincere warmth are important foundations in educating children

The relationship of love in the family is not limited to feelings, but also involves maintenance, a sense of responsibility, care, understanding, respect, and a desire to develop the child and each member of the family. It is important to provide affection in the family with respect, courtesy, and responsibility (obligation) between husband and wife, parents and children, and siblings.

By carrying out the obligations and rights of each family member, it can create an atmosphere full of love (mawaddah wa rahmah). Both must be careful of responsibilities. The creativity of husband and wife in creating affection in all aspects and loving with a strong foundation can overcome a relationship that only focuses on bodily satisfaction. Such love unites and complements each other between two different persons.

The third theme is related to death and the hereafter. The afterlife and death issues are also a concern for poor women in urban areas. It is recognized that, in essence, the life of the world was created by Allah to test humans, which of them is better at doing. The world's life determines the good and bad of life in the hereafter because Rasulullah SAW said life is a field for the afterlife. This means that if the field is planted with various useful and wellpreserved plants, the crops will be harvested with satisfactory results. Therefore, in this life, if we do righteous deeds, then we will reap the results in the afterlife in happiness and beauty of eternal life after death.

The middle between the phase of the world and the phase of the hereafter is called the barzakh, which is a realm of waiting for people who have died heading to the day of judgment. They are all waiting for the arrival of the great apocalypse marked by the blowing of the first trumpet. Humans to get pleasure and happiness in the hereafter, then he must try to be a person who obeys Allah while in the world, by carrying out all his commands and avoiding all his prohibitions or, in other words, increasing righteous deeds.

The next theme is moral. The issue of morality is also of interest to poor women in the Tallo district. It is recognized that in Islamic teachings, the principles of morality are in the form of Al-Qur' an and the Sunnah of the Prophet Muhammad. Good and bad in Islamic morals are good and bad according to the two sources, not human standards. Because if the standard is human, the good and bad can be various. Someone says that something is good, but other people do not necessarily think it is good. Vice versa, someone calls something bad, even though others might call it good.

Therefore, through the Qur'an and the Sunnah of the Prophet Muhammad, we can understand that the characteristics of patience, tawakkal, gratitude, forgiveness, and generosity are good and noble qualities. Conversely, we also understand that the characteristics of shirk, kufr, nifaq, ujub, takabur, and hasad are despicable qualities. If the two sources do not confirm the value of these traits, human reason may give different values. However, Islam does not deny other standards besides the Al-Qur'an and Sunnah to determine the good and bad of human morals. The position of morals towards Islamic education is significant and becomes a pillar above all.

\section{The Effective and Accessible Preaching Media}

Methods of preaching are certain methods used by a da'i (communicator) to mad' $u$ to achieve a goal based on wisdom and compassion. This implies that the preaching approach must be based on a human-oriented view of placing noble respect on human beings. The method of preaching includes three scopes (Munir, 2009), namely: (1) AlHikmah, which means that wisdom in the world of preaching has a very important position, it can determine the success or failure of preaching, (2) Al-Mau'idza Al-Hasanah, which is interpreted as an expression that 
contains elements of guidance, education, teaching, stories, happy news, warnings, and positive messages (wasiyat) that can be used as guidelines in life to get the safety of the world and the hereafter, and (3) Al-Mujadalah Bi-alLati Hiya Ahsan, which means an effort to exchange opinions carried out by the two parties in synergy, without any atmosphere that necessitates the birth of hostility between the two.

Based on the data analysis of this research, several preaching media which are considered practical and easily accessible to poor women in the Tallo district are direct dialogue or lectures, electronic media, and social media. Furthermore, the three media of preaching and the rankings of its affordability and easy access for the community will be discussed. Such media are dialogue or direct lectures $(50 \%)$, electronic media (TV or Radio) (40\%), and internet and social media $(10 \%)$. Detail all of those percentages can be seen in graph 7.

Graph 7. Preaching Media That

Considered Effective and Accessible

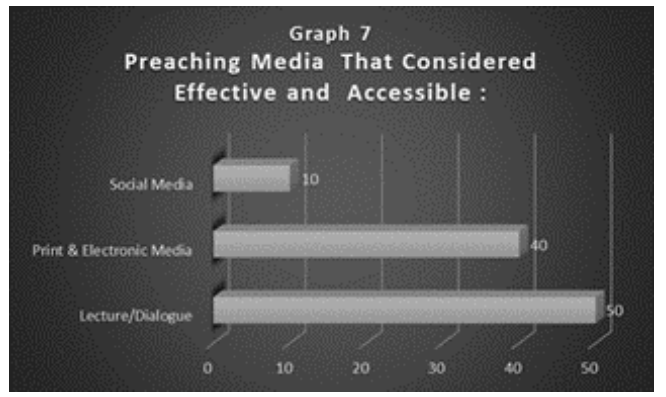

From the description above, it can be seen that the majority of poor women in the Tallo district think that the lecture or face-toface method is considered the easiest to access and understand. The lecture method is a method that is carried out to convey information, instructions, understanding, and explanations of a problem in front of many people. This is also related to the persistence of Islam which instructs its ummah to be civilized and ethical in speaking. This is also what causes the da'i to become wise people, proficient in delivering lectures, opinions, and understanding to the mad'u. Da'i must also understand from which door he must enter each house and how to enter that house. Da'i tries to convince people about the truth of what it presents, then tries to get people to move to practice what they teach (Munir, 2013).

In such situation, the $d a^{\prime} i$ is expected to speak in a language that makes an impression in their mad'u's heart. In order not to slip into speech, da'i needs four conditions. The first way is choosing only good words. A good speech can nurture mutual affection, strengthen friendship, and prevent the deceit of Satan, who tries to ruin relationships and cause disputes. The following condition is putting the conversation in its proper place. Conversations that do not contain benefits are neglected and left behind (ignored). If the conversation which should be ended, then put first, then obscured, is slowness and weakness. The next way is talking with the conversation is just a necessity. There are two talks that do not meet these needs, which are short ones that destroy meaning, and long ones that distracts focus and conveys something in unclear language, so that they are not understood. The last situation is choosing words to be discussed. The speech of someone whose speech is stiff, lacks passion, and has no direction shows that his heart is like that too.

It is also explained that many people are good at speaking and conveying theories fluently, but only a few put their words into practice. This is where the urgency of the qudwah hasanah (portrait of good exemplary) is seen in the community, whose job is to translate theories of goodness into real practice so that the theory is not always depicted on sheets of paper. Therefore, preaching with noble morals means practicing noble morals to spread the truth to the human.

The second, easily accessible media of preaching is electronic media, such as radio and television. One of the most accessible communication media today is television. Television can be used to convey messages of preaching or Islamic teachings to the general public, especially the poor. The advantages and characteristics of television as preaching media, especially in its closeness to everyday life, offer a framework and cultural expression that are technologically and institutionally unique, such as the expression of broader social, political, and economic forces. Television also has a very wide reach in disseminating messages quickly with all its impacts on the lives of individuals and society. 
The Indonesian people are more interested in preaching which is interspersed with jokes than only describes Islamic material. Therefore, preaching through television with lecturers who are well versed in Islamic material is not necessarily well received by viewers if the delivery is monotonous and flat without any element of humor. On the other hand, an ustadz with scientific limitations will be more accepted and become an idol if he can package his description with humor, jokes, and an attractive appearance.

Muhyiddin (2002) explains, as a means or wasilah, television as the media of preaching has advantages compared to other media. First, television has a very wide reach, so that the expansion of preaching can reach farther places. Even preaching messages can be delivered to $\mathrm{mad}^{\prime} u$ who are in places that are not difficult to reach. Second, television can touch honey that is heterogeneous and in large numbers. This is consistent with one of the characteristics of mass communication, namely heterogeneous and scattered communicants. Third, television can accommodate various preaching methods so that it opens opportunities for preachers to spur creativity in developing the most effective preaching methods. Fourth, television media is audio-visual. This allows preaching to be carried out by displaying speech and visualizing images.

Regarding access to preaching media through the internet and social media, very few poor women can access it even though they understood it was something quite new. They know that the Internet is the most sophisticated media and source of information today because this technology offers various conveniences, speeds, the accuracy of access, and the ability to provide various information needs for everyone, anytime, anywhere, and at any level. Thus, internet access is a medium that cannot be avoided because it has become a new civilization in the world of information and communication at the global level. By using internet access, the international community can access a lot of information for personal, educational, business, and other purposes. The internet network is a revolution in the world of communication and information.
As a form of technological advancement in the field of communication technology, the internet is a means or media that preachers can use in carrying out their preaching activities. This is possible as long as the $d a^{\prime} i$ have adequate provisions in terms of information technology. Da'i or scholars who are not responsive to technology are no longer valid. It's not the time for a $d a^{\prime} i$ against technology, especially technology that can facilitate preaching. The internet can be used as a medium to facilitate preaching. The sites related to Islam on the Internet are also a kind of preaching.

It is quite understood that a large number of internet users is one of the supporters of preaching in social media. They take advantage of social media as a new platform for growth. The scholars use social media as an effective way of preaching. Then, he also stated that the use of internet by the people today had become a daily necessity. This has become a great potential for developing preaching through social media. Another aspect that supports preaching through social media is that many people are still unfamiliar with religious knowledge. Thus, scholars conduct preaching through social media to invite the public to make more use of the internet as a place to increase knowledge.

On one side, social media has now become very useful, especially for preachers. One of the factors that encourage preaching through social media is the convenience provided by the internet. The dissemination of Islamic teachings can be packaged briefly, quickly, broadly, attractively, and effectively. A large number of internet users in Indonesia is also a factor in the emergence of preaching through social media. Coupled with this social media, now it has become a necessity of life for internet users. Preaching carried out through social media certainly has many advantages for preachers in particular. Apart from preachers, benefits can also be felt for social media users. Social media users can access freely without the limitation of time and place.

However, on the other hand, social media also negatively impacts the internet user community. One example is that social media can easily be imitated and misused by 
irresponsible people against this mission's teachings of. Preaching through social media also causes misinterpretation. The understanding obtained is likely to differ from the delivery of the message in question. This also cannot be separated from the role of the media, which is only one-way communication. If this is continuous, it can eliminate the true meaning of the teachings. The interaction in preaching is important for preachers and society itself. Direct preaching is more interactive and efficient in delivering preaching messages.

\section{CLOSING}

The description of social situations and conditions is one of the important aspects that must be considered in planning the preaching activities in the community. This research then became a challenge in itself since it was aimed at poor women in one of the districts (Tallo) in Makassar with a preaching communication approach. The current situation and condition of the Tallo poor women show that local religious leaders (Ustadz and Imam) are still idols and role models. Although, the one who is considered the most responsible for fulfilling their needs and carrying out preaching for them is the government. This correlates significantly with the understanding of those who mostly define preaching as an activity that must be carried out in dialogue and face to face.

Dealing with the preaching message they are interested in, worship rituals such as prayer and fasting are still a major need to be studied because it is related to obligations as Muslims. On the one hand, the need and desire to live in a harmonious, peaceful, and happy family atmosphere remains a dream. They also still yearn for messages that remind us of the need always to have good morals and respect one another, both as fellow Muslim communities or adherents of other religions.

The preaching media that are considered more effective and accessible are through direct dialogue or lectures. They also still need other electronic media, such as radio and television, as information, education, and entertainment in preaching media. However, their access to social media is still limited.

Behind all the needs and desires mentioned earlier, they highly need the attention of all parties, especially the government, to improve and develop a better life. In this case, they first need decent living conditions to be actively involved and participate in preaching activities in their environment. Therefore, it is necessary to integrate preaching activities and sustainably develop their potential. However, a gender analysis is needed both in preaching activities and women's poverty alleviation programs to help identify gender inequality as an important aspect of poverty and prepare a more comprehensive design and preaching strategy.

\section{ACKNOWLEDGEMENT}

The author would like to thank all those who contributed to this research. In particular, thanks to all the editors of the journal Al-Qalam Makassar Research and Development Institute for Religion who published this paper.

\section{REFERENCES}

Bastomi, Hasan. 2016. Dakwah Melalui Gerakan Bersedekah: Tinjauan Implementasi Program Pada Pppa Darul Qur'an. Jurnal -Membangun Profesionalisme Keilmuan. Edisi Juli Desember 2016

BPS Kota Makassar.2016. Statistik Daerah Kecamatan Tallo. BPS Kota Makassar

BPS Kota Makassar. 2019. Kecamatan Tallo dalam Angka. BPS Kota Makassar.

Dinas Sosial. 2019. Jumlah Penduduk Miskin - Keluarga Kota Makassar Tahun 2019. https://integrasidata.id/data/jumlahpenduduk-miskin-keluarga-kotamakassar-tahun-2019/ diakses Desember 2020

Djaelani, Abul Qadir. 1990. Peran Ulama dan Santri dalam Perjuangan Politik Islam di Indonesia. Surabaya: PT. Bina.

Ilaihi, Wahyu. 2010. Komunikasi Dakwah. Bandung: PT Remaja Rosdakarya

Isdijoso,Widjajanti et.al. 2016, Penetapan Kriteria dan Variabel Pendataan Penduduk Miskin yang Komprehensif dalam Rangka Perlindungan Penduduk Miskin di Kabupaten/Kota, Kertas 
Kerja SMERU, The SMERU Research Institute, September 2016

Kumurur, Veronica A .2009. Pembangunan Dan Kemiskinan Perempuan Di Kota. EKOTON Vol. 9, No.1: 73-86, April 2009. 73-87

Masrizal. 2011. Mixed Method Research. Jurnal Kesehatan Masyarakat, September 2011-Maret 2011, Vol. 6, No.1 53-56

Milles dan Huberman. 1992. Analisis Data Kualitatif, Jakarta: Universitas Indonesia Press,

Moghadam, V.M. 2005. Globalizing women: Transnational feminist networks. MD: The Johns Hopkins University Press. Baltimore

Muhyidin, Asep dan Safei Agus.2002. Ahmad, Metode Pengembangan Dakwah, Bandung: Pustaka Setia.

Munir dkk. 2013. Metode Dakwah. Jakarta : Prenada Media

Munir. 2009. Metode Dakwah. Jakarta : Kencana

Muslimin, Abd. Aziz. 2013. Kemiskinan Dan Perilaku Sosial Masyarakat Perkotaan, Equilibrium Jurnal Pendidikan Volume I No. $1 / 2013$, h. 34

Noerdin et al. 2006. Potret Kemiskinan Perempuan. Jakarta: Women Research Intitute.

Hasanah,Siti. 2013. Pemberdayaan Perempuan Melalui Kegiatan Ekonomi Berkeadilan (Simpan Pinjam Syariah Perempuan). SAWWA - Volume 9, Nomor 1, Oktober 2013, 71-88
Sa'dan, Masthuriah. 2016. Rekonstruksi Materi Dakwah untuk Pemberdayaan Perempuan: Perspektif Teologi Feminisme. HARKAT ISSN 14122324): Media Komunikasi Islam Tentang Gender dan Anak, 12 (1), 2016, 34-45

Saputra, Wahidin. 2010. Pengantar Ilmu Dakwah. Jakarta: Rajawali Pers,

Sholehah, Mar'atus. 2018. Dakwah Untuk Pemberdayaan Perempuan Dalam Pembangunan Pertanian Di Perdesaan. Jurnal Ilmu Dakwah, Vol. 38, No.2, Juli - Desember 2018 ISSN 1693-8054. (204-218)

Todaro, M.P. 2000. Pembangunan Ekonomi, diterjemahkan oleh Haris Munandar. Jakarta : Bumi Aksara Jakarta.

Zaini, Ahmad. 2017. Dakwah dan Pemberdayaan Masyarakat Pedesaan Jurnal Ilmu Dakwah, Vol. 37, No.2, Juli - Desember 2017 ISSN 1693-8054. 284-301

Wahid, A. (2006). Islamku, Islam Anda, Islam Kita: Agama Masyarakat dan Negara Demokrasi. The Wahid Institute.

Wahid, A. (2010). Menggerakkan Tradisi: Esai-esai Pesantren. Lkis.

Widayanti, S. (2020). Pesantren and Social Empowerment: A Critical Analysis On Pesantren Al-Imdad Yogyakarta And Pesantren Maslakul Huda Central Java. Analisa: Journal of Social Science and Religion, 5(01), 51-70. https://doi.org/10.18784/analisa.v5i1.10 55

Zubaedi. (2007). Wacana Pembangunan Alternatif. Ar-Ruzz Media. 